\title{
Structural characterization and effects on corticosteroid secretion of endothelin-1 and endothelin-3 from the frog Rana ridibunda
}

\author{
Y Wang ${ }^{1}$, I Remy-Jouet ${ }^{2}$, C Delarue ${ }^{2}$, M Letourneau ${ }^{3}$, A Fournier $^{3}$, \\ $\mathbf{H}$ Vaudry $^{2}$ and $\mathbf{J}$ M Conlon ${ }^{1}$ \\ ${ }^{1}$ Regulatory Peptide Center, Department of Biomedical Sciences, Creighton University Medical School, \\ Omaha, Nebraska 68178-0405, USA \\ ${ }^{2}$ European Institute for Peptide Research, Laboratory of Cellular and Molecular Neuroendocrinology, \\ INSERM U-413, CNRS, University of Rouen, 76821 Mont-Saint-Aignan, France \\ ${ }^{3}$ INRS/Institut Armand Frappier, Université du Québec, Pointe-Claire, Québec, Canada H9R 1G6
}

(Requests for offprints should be addressed to J M Conlon; Email: jmconlon@creighton.edu)

\begin{abstract}
Despite the intensive study of endothelin (ET) in mammals, the primary structure and biological activity of the peptide is not known for any species of non-mammalian tetrapod. Extracts of the stomach and the liver of the European green frog Rana ridibunda contained ET-like immunoreactivity measured by RIA using an antiserum raised against human ET-1. The amino acid sequence of the peptide that was isolated in pure form from the stomach extract was identical to that of human ET-1 and the peptide purified from the liver extract was identical to human ET-3 except for a single amino acid substitution $\left(\mathrm{Phe}^{4} \rightarrow \mathrm{Tyr}\right)$. These observations demonstrate that the amino acid sequences of ET family peptides have been very strongly conserved during evolution of tetrapods and suggest that the pathway of post-translational processing of preproendothelin in the frog is similar to that in
\end{abstract}

mammals. Both frog/human ET-1, frog ET-3 and human ET-3 produced a concentration-dependent increase in the production of corticosteroids from perifused slices of the frog interrenal gland. The maximum responses produced by the peptides (approximately 2 -fold increase over basal levels for both corticosterone and aldosterone production) were not significantly different. The potency of ET-1 ( $-\log \mathrm{EC}_{50}=9 \cdot 81 \pm 0 \cdot 01$ (s.E.M.) for corticosterone and $9 \cdot 52 \pm 0 \cdot 29$ for aldosterone production) was significantly $(P<0 \cdot 01)$ greater than that of frog ET-3 $\left(-\log \quad \mathrm{EC}_{50}=8 \cdot 13 \pm 1.6\right.$ for corticosterone and $8 \cdot 15 \pm 0 \cdot 33$ for aldosterone production) but the potencies of frog ET-3 and human ET-3 ( $-\log$ $\mathrm{EC}_{50}=8 \cdot 29 \pm 0 \cdot 34$ and $\left.7 \cdot 87 \pm 0 \cdot 18\right)$ were not significantly different.

Fournal of Molecular Endocrinology (2000) 24, 285-293

\section{INTRODUCTION}

The endothelin (ET) family of peptides (ET-1, ET-2 and ET-3 (Inoue et al. 1989)) play important and diverse roles in the regulation of mammalian physiological processes and in the pathophysiology of human diseases (Rubanyi \& Polokoff 1994). However, our understanding of the structural and biological properties of ETs from non-mammalian species is very limited. There is strong evidence that the tissues of Anura (frogs and toads) synthesize ET-related peptides and express ET receptors and that ET displays similar biological actions in amphibians as in mammals. Using an ET-3 specific antiserum in immunohistochemistry, ET-3-like immunoreactivity was detected in gonadotrophs distributed throughout the pars distalis of the pituitary of the female bullfrog, Rana catesbeiana (Suzuki et al. 1997). High affinity ET-1 binding sites have been identified in liver (Nambi et al. 1994), heart (Kumar et al. 1994) and oocytes (Kumar et al. 1993) of the toad Xenopus laevis and recently two Xenopus ET receptor subtypes have been cloned and characterized: $\mathrm{ET}_{\mathrm{Ax}}$ from heart (Kumar et al. 1994) and $\mathrm{ET}_{\mathrm{C}}$ from dermal melanophores (Karne et al. 1993). 
Functional studies have shown that the vascular tissues of amphibia are extremely sensitive to ET, suggesting that the cardiovascular role of this peptide has been highly conserved during the course of vertebrate evolution. For example, human ET-1 potently $\left(\mathrm{EC}_{50}<10 \mathrm{nM}\right)$ constricts isolated vascular rings prepared from arteries and veins of the frog $R$. pipiens (Poder et al. 1991), and the toad Bufo viridis (Doi \& Fujimoto 1993). In several species of mammal (Cozza et al. 1989, Morishita et al. 1989, Belloni et al. 1996, Rossi et al. 1997), ET-1 stimulates steroidogenesis in dispersed cells from the glomerulosa zone of the adrenal cortex and it has been shown that synthetic human ET-1 stimulates both corticosterone and aldosterone production by perifused frog interrenal slices from the frog $R$. ridibunda (Delarue et al. 1990).

Prior to the onset of our program of study, the only non-mammalian ET-like peptides to have been characterized structurally were the sarafotoxins, a family of five isoforms isolated from the venom of the snake, Atractaspis engaddensis (Takasaki et al. 1988). The sarafotoxins, like the ETs, comprise 21 amino acid residues, possess the same pattern of disulfide linkages and exhibit strong vasoconstrictor activity, but the evolutionary relationships between the two families is unclear (Takasaki et al. 1992). In most mammalian tissues, ET is secreted by the constitutive pathway (Nakamura et al. 1990) with the result that steady-state concentrations of the peptide are very low. This poses a challenge to the peptide chemist to obtain sufficient pure material to permit structural characterization, but recent advances in the instrumentation of microsequence analysis allow amino acid sequence determination of very low picomole amounts of peptide. The present study extends our understanding of the evolution of the ET family of peptides by describing the purification, structural characterization and steroidogenic activity in the species of origin of ET-1 and ET-3 from the European green frog $R$. ridibunda.

\section{MATERIALS AND METHODS}

\section{Materials}

Human ET-1 was synthesized as previously described (Forget et al. 1996). (3-[125I]Iodotyrosyl) ET-1 (specific activity $74 \mathrm{TBq} / \mathrm{mmol}$ ) was supplied by Amersham Life Science, Arlington Heights, IL, USA).

\section{Tissue extraction}

Adult specimens of the European frog $(R$. ridibunda) were obtained from a commercial source
(Couetard, St-Hilaire de Riez, France). Whole stomachs and livers were collected from 2000 animals and immediately frozen on dry ice. The frozen tissues (stomach $1.1 \mathrm{~kg}$ wet weight; liver $1.5 \mathrm{~kg}$ wet weight) were separately homogenized in ethanol $/ 0 \cdot 7 \mathrm{M} \mathrm{HCl}(3: 1 \mathrm{v} / \mathrm{v} ; 8 \mathrm{ml} / \mathrm{g}$ tissue $)$ at $0{ }^{\circ} \mathrm{C}$ using a Waring blender. After centrifugation $\left(1600 \mathrm{~g}, 30 \mathrm{~min}, 4^{\circ} \mathrm{C}\right)$, ethanol was removed from each supernatant under reduced pressure. After a further centrifugation $\left(1600 \mathrm{~g}, 30 \mathrm{~min}, 4{ }^{\circ} \mathrm{C}\right)$, peptide material was isolated from the supernatants by passage through fifteen Sep-Pak C18 cartridges (Waters Associates, Milford, MA, USA) connected in series as previously described (Chartrel et al. 1995). Bound material was eluted from the cartridges with $70 \%(\mathrm{v} / \mathrm{v})$ acetonitrile/water and lyophilized.

\section{RIAs}

ET-like immunoreactivity (ET-LI) was measured using an antiserum raised against human ET-1 that shows $60 \%$ cross-reactivity with human ET-2, 70\% cross-reactivity with human ET-3, but only $0 \cdot 1 \%$ reactivity with 'big' human ET-1 (1-38) ('Takahashi et al. 1991). ${ }^{125}$ I-Labeled human ET-1 was used as tracer. The minimum detectable concentration using human ET-1 as standard was approximately $2 \mathrm{fmol} /$ tube. Corticosterone and aldosterone concentrations were determined by RIA without prior extraction, as previously described (Delarue et al. 1990). The intra- and interassay coefficients of variation were lower than 4 and $10 \%$ respectively.

\section{Purification of ET-1 from frog stomach}

The stomach extract, after partial purification on Sep-Pak cartridges, was redissolved in $1 \%(\mathrm{v} / \mathrm{v})$ trifluoroacetic acid/water $(10 \mathrm{ml})$ and chromatographed on a $2.5 \times 100 \mathrm{~cm}$ column of Sephadex G-25 (Pharmacia Biotech, Uppsala, Sweden) equilibrated with $1 \mathrm{M}$ acetic acid. The column was eluted at a flow rate of $48 \mathrm{ml} / \mathrm{h}$ and fractions $(8 \mathrm{ml})$ were collected. Absorbance was measured at $280 \mathrm{~nm}$. The concentration of ET-LI in the fractions was determined by RIA at a dilution of 1:30. Fractions containing ET-LI were pooled and pumped onto a $1 \times 25 \mathrm{~cm}$ Vydac 218TP510 (C-18) reverse-phase HPLC column (Separations Group, Hesperia, CA, USA) equilibrated with $0 \cdot 1 \%(\mathrm{v} / \mathrm{v})$ trifluoroacetic acid/water at a flow rate of $2 \mathrm{ml} / \mathrm{min}$. The concentration of acetonitrile in the eluting solvent was raised to $21 \%$ over $10 \mathrm{~min}$, held at this concentration for $30 \mathrm{~min}$ and raised to $49 \%$ over $60 \mathrm{~min}$ using linear gradients. Absorbance was monitored at 214 and $280 \mathrm{~nm}$ and fractions (1 min) 
were collected. The fraction containing ET-LI was successively chromatographed on a $0.46 \times 25 \mathrm{~cm}$ Vydac 214TP54 (C-4) column, a $0.46 \times 25 \mathrm{~cm}$ Vydac 219TP54 (phenyl) column and a $0.46 \times$ $25 \mathrm{~cm}$ Vydac 218TP54 (C-18) column at a flow rate of $1.5 \mathrm{ml} / \mathrm{min}$ using the elution conditions indicated in Fig. 1.

\section{Purification of ET-3 from frog liver}

The liver extract, after partial purification on Sep-Pak cartridges, was redissolved in $1 \%(\mathrm{v} / \mathrm{v})$ trifluoroacetic acid/water $(10 \mathrm{ml})$ and subjected to gel permeation chromatography on Sephadex G-25 under the same conditions used for the stomach extract. Frog ET-3 was purified to near homogeneity by successive chromatographies on a $1 \times 25 \mathrm{~cm}$ Vydac 218TP510 (C-18) reverse-phase HPLC column and on $0.46 \times 25 \mathrm{~cm}$ Vydac 214TP54 (C-4), Vydac 219TP54 (phenyl) and Vydac 218TP54 (C-18) columns under the same conditions used for purification of ET-1 from the stomach extract.

\section{Structural analysis}

The primary structures of the peptides were determined by automated Edman degradation using a Procise 491A sequenator (Perkin-Elmer, Foster City, CA, USA). Mass spectrometry of the peptide was performed on a Voyager RP MALDI-TOF instrument (Perspective Biosystems Inc., Framingham, MA, USA) equipped with a nitrogen laser $(337 \mathrm{~nm})$. The instrument was operated in linear mode with delayed extraction and the accelerating voltage in the ion source was $25 \mathrm{kV}$. Approximately $10 \mathrm{pmol}$ of sample was used and the accuracy of the mass determinations was at least $0 \cdot 05 \%$.

\section{Peptide synthesis}

Frog ET-3 was synthesized using a manual solid-phase synthesizer according to Fmoc chemistry protocols. A hydroxymethylated resin (Wang resin) with a substitution of $1.12 \mathrm{mmol} / \mathrm{g}$, was used as a solid support. Every coupling was monitored with the use of the ninhydrin test. The peptide was cleaved from the solid support with liquid hydrofluoric acid $(10 \mathrm{ml} / \mathrm{g})$ in the presence of $m$-cresol $(1 \mathrm{ml} / \mathrm{g})$ and dimethylsulfide $(1 \mathrm{ml} / \mathrm{g})$ as scavengers. The crude material was purified by preparative reverse-phase HPLC using a linear gradient of trifluoroacetic acid/water $(0 \cdot 06 \%)$ and acetonitrile for elution. The fractions corresponding to the purified linear ET were pooled and lyophilized. To cyclize the peptide, the lyophilized

www.endocrinology.org material was dissolved in degassed aqueous acetic acid $(80 \%)$, and a solution of iodine (50 equivalents) in methanol was added dropwise. The reaction was monitored by analytical HPLC and it was stopped by the addition of ascorbic acid. The peptide was purified by preparative HPLC and its identity confirmed by electrospray mass spectrometry.

\section{Biological activity}

The effects of synthetic frog ET-1 and ET-3 on the secretion of corticosterone and aldosterone by perifused adrenal glands of the frog $R$. ridibunda were carried out as previously described (Delarue et al. 1990). In brief, the adrenal (interrenal) glands were carefully dissected, freed of kidney tissue, sliced with scissors and preincubated in $5 \mathrm{ml}$ Ringer's solution (15 mM Hepes buffer, $112 \mathrm{mM}$ $\mathrm{NaCl}, 2 \mathrm{mM} \mathrm{CaCl}, 2 \mathrm{mM} \mathrm{KCl}$, and $15 \mathrm{mM}$ $\mathrm{NaHCO}_{3}$ ) supplemented with $2 \mathrm{mg} / \mathrm{ml}$ glucose and $0.3 \mathrm{mg} / \mathrm{ml} \mathrm{BSA}$. The Ringer's solution was gassed with $\mathrm{O}_{2} / \mathrm{CO}_{2}(95 \% / 5 \%)$, and the $\mathrm{pH}$ was adjusted to $7 \cdot 4$. The tissue slices were rinsed three times with fresh medium and layered between several beds of Bio-Gel P2 into perifusion chambers (equivalent of 12 glands per chamber). The adrenal tissue was continuously perifused with gassed Ringer's solution at a constant flow rate $(200 \mu \mathrm{l} / \mathrm{min})$ and temperature $\left(24^{\circ} \mathrm{C}\right)$. The experimental procedure commenced after a stabilization period of $2 \mathrm{~h}$. ET-1 or ET-3 was dissolved in gassed Ringer's solution and infused into the columns at the same flow rate as Ringer's solution alone. Fractions of perifusate effluent were collected every $5 \mathrm{~min}$ and immediately frozen until assay. Concentration-response curves were constructed using a SigmaPlot program (Jeandel Scientific, San Rafael, CA, USA) and potencies ( $-\log \mathrm{EC}_{50}$ values) and efficacies (percent increase over mean basal rates of secretion) were calculated using the program. Basal rates were calculated as the mean of eight samples (40 min) collected at the beginning of the perfusion experiment. Data points show means ( \pm s.E.M.) for between three and eight independent experiments. Data were compared using ANOVA and the Tukey-Kramer multiple comparisons test. A $P$ value of $<0.05$ was considered to be significant.

\section{RESULTS}

\section{Purification of the peptides}

The extract of frog stomach, after partial purification on Sep-Pak cartridges, was subjected to gel permeation chromatography on a Sephadex G-25 column. ET-LI was eluted as a broad peak with 

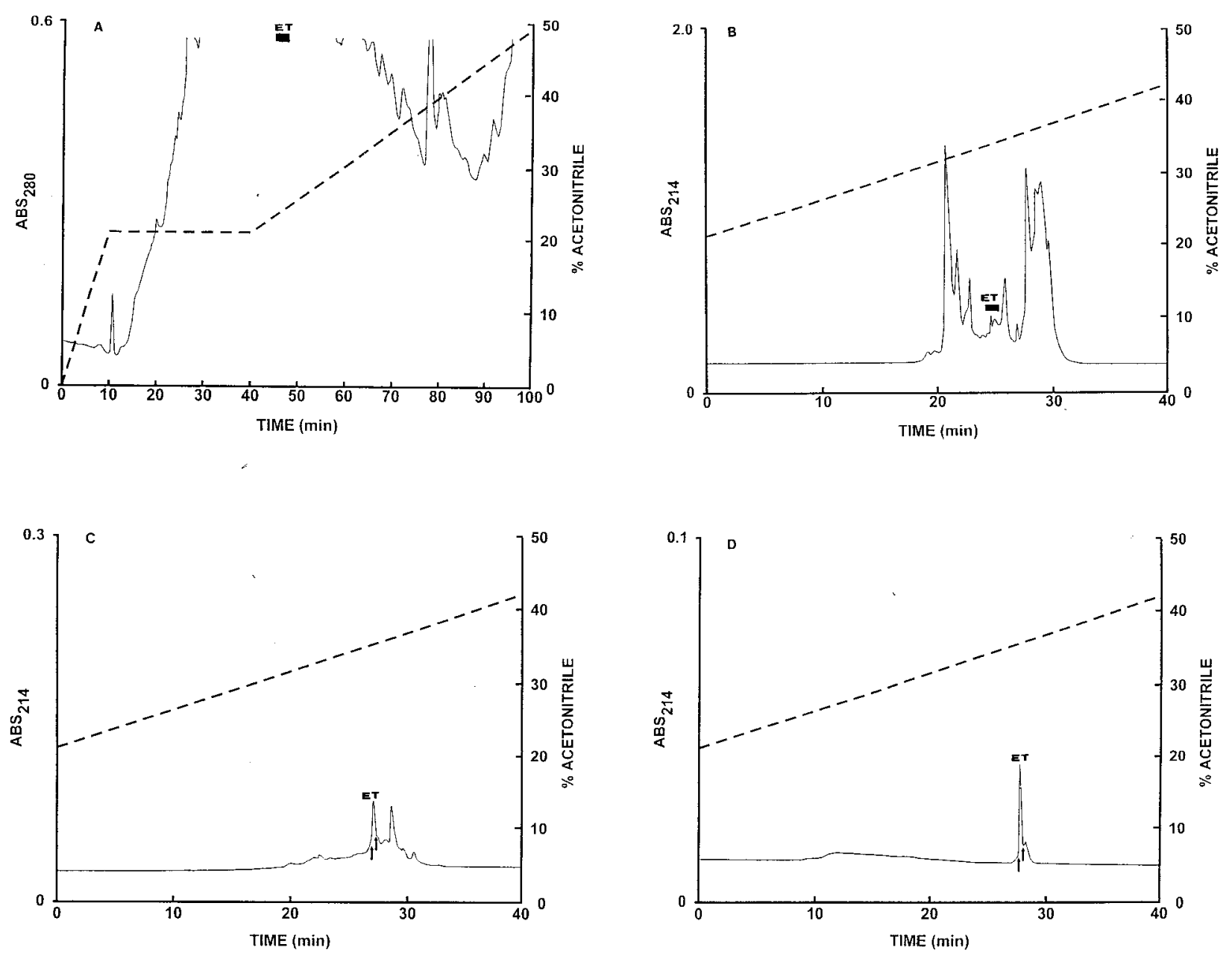

FIGURE 1. Purification of ET-1 from an extract of frog stomach by reverse-phase HPLC on (A) semi-preparative Vydac C-18, (B) analytical Vydac C-4, (C) analytical Vydac phenyl and (D) analytical Vydac C-18 columns. The columns were eluted at a flow rate of $1.5 \mathrm{ml} / \mathrm{min}(2 \mathrm{ml} / \mathrm{min}$ in $(\mathrm{A}))$ with linear gradients of increasing acetonitrile concentrations, denoted by the dashed lines. The fractions denoted by the bars contained ET-LI and the arrows show where peak collection began and ended.

$\mathrm{K}_{\mathrm{AV}}$ between $0 \cdot 55$ and $0 \cdot 75$. These fractions were pooled and chromatographed on a semi-preparative Vydac C-18 column and the elution profile is shown in Fig. 1A. ET-LI was associated with the fraction denoted by the bar. Frog ET-1 was purified to near homogeneity, as assessed by peak symmetry, by successive chromatographies on an analytical Vydac C-4 column (Fig. 1B), an analytical Vydac phenyl column (Fig. 1C) and an analytical Vydac C-18 column (Fig. 1D). The final yield of pure peptide was approximately 30 pmol.

The ET-LI in the extract of frog liver, after partial purification on Sep-Pak cartridges, was also eluted from a Sephadex G-25 gel permeation column as a broad peak with approximately the same elution volume as the gastric ET. Frog ET-3 was purified to near homogeneity by reverse-phase HPLC under the same conditions of chromatography used to purify frog ET-1. The elution profiles are shown in Fig. 2A-D. The final yield of pure peptide was approximately $40 \mathrm{pmol}$.

\section{Structural characterization}

The primary structures of frog ET-1 and ET-3 were determined by Edman degradation using an automated microsequence analyzer. The amino acid sequence of frog ET-1 was established as: Xaa-SerXaa-Ser-Ser-Leu-Met-Asp-Lys-Glu-Xaa-Val-TyrPhe-Xaa-His-Leu-Asp-Ile-Ile-Trp. No phenylthiohydantoin-coupled amino acid derivatives were detected during cycles 1, 3, 11 and 15. This is 

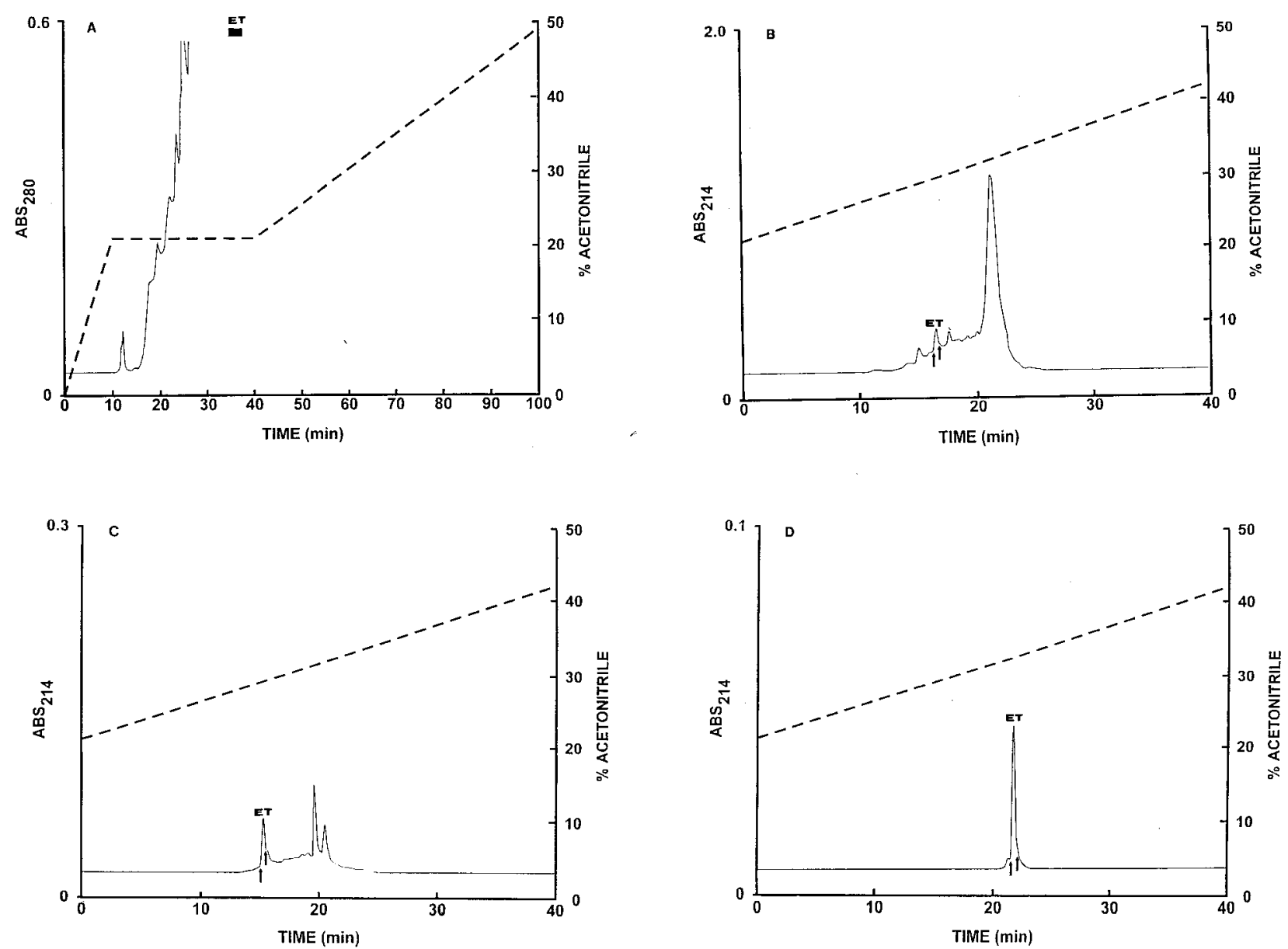

FIGURE 2. Purification of ET-3 from an extract of frog liver by reverse-phase HPLC on (A) semi-preparative Vydac C-18, (B) analytical Vydac C-4, (C) analytical Vydac phenyl and (D) analytical Vydac C-18 columns. The conditions of chromatography were the same as those shown in Fig. 1. The fractions denoted by the bars contained ET-LI and the arrows show where peak collection began and ended.

consistent with the presence of cystine residues at these positions and so $\mathrm{Xaa}$ is assumed to be cysteine. The structure of frog ET-1, including the presence of two disulfide bridges, was confirmed by mass spectrometry using internal calibrants. The observed molecular mass of the peptide was $2492 \cdot 0 \pm 0 \cdot 2$ compared with a calculated average molecular mass of $2492 \cdot 0$ for the proposed structure.

The primary structure of frog ET-3 was established as: Xaa-Thr-Xaa-Tyr-Thr-TyrLys-Asp-Lys-Glu-Xaa-Val-Tyr-Tyr-Xaa-HisLeu-Asp-Ile-Ile-Trp. Again, no phenylthiohydantoin-coupled amino acid derivative was detected during cycles 1, 3, 11 and 15. The proposed amino acid sequence, including the presence of two cystine bridges was confirmed by mass spectrometry without internal calibration (observed average molecular mass $2658 \pm 1$; calculated average molecular mass of 2659).

\section{Effect of ET-1 and ET-3 on corticosteroid secretion}

It has been previously shown that repeated pulses of ET-1 cause attenuation of the response of frog adrenal tissue to the peptide (Delarue et al. 1990). To avoid tachyphylaxis, a single pulse of ET-1 or ET-3 was administered to perifused adrenal slices. Administration of graded concentrations of ET-1 $\left(10^{-11}\right.$ to $\left.10^{-8} \mathrm{M}\right)$, human ET-3 $\left(10^{-10}\right.$ to $\left.5 \times 10^{-7} \mathrm{M}\right)$ and frog ET-3 $\left(10^{-10}\right.$ to $\left.5 \times 10^{-7} \mathrm{M}\right)$ to perifused adrenal slices stimulated corticosterone and aldosterone secretion in a dose-dependent manner (Fig. 3). The potencies and efficacies (percent maximum response over basal levels) of the 

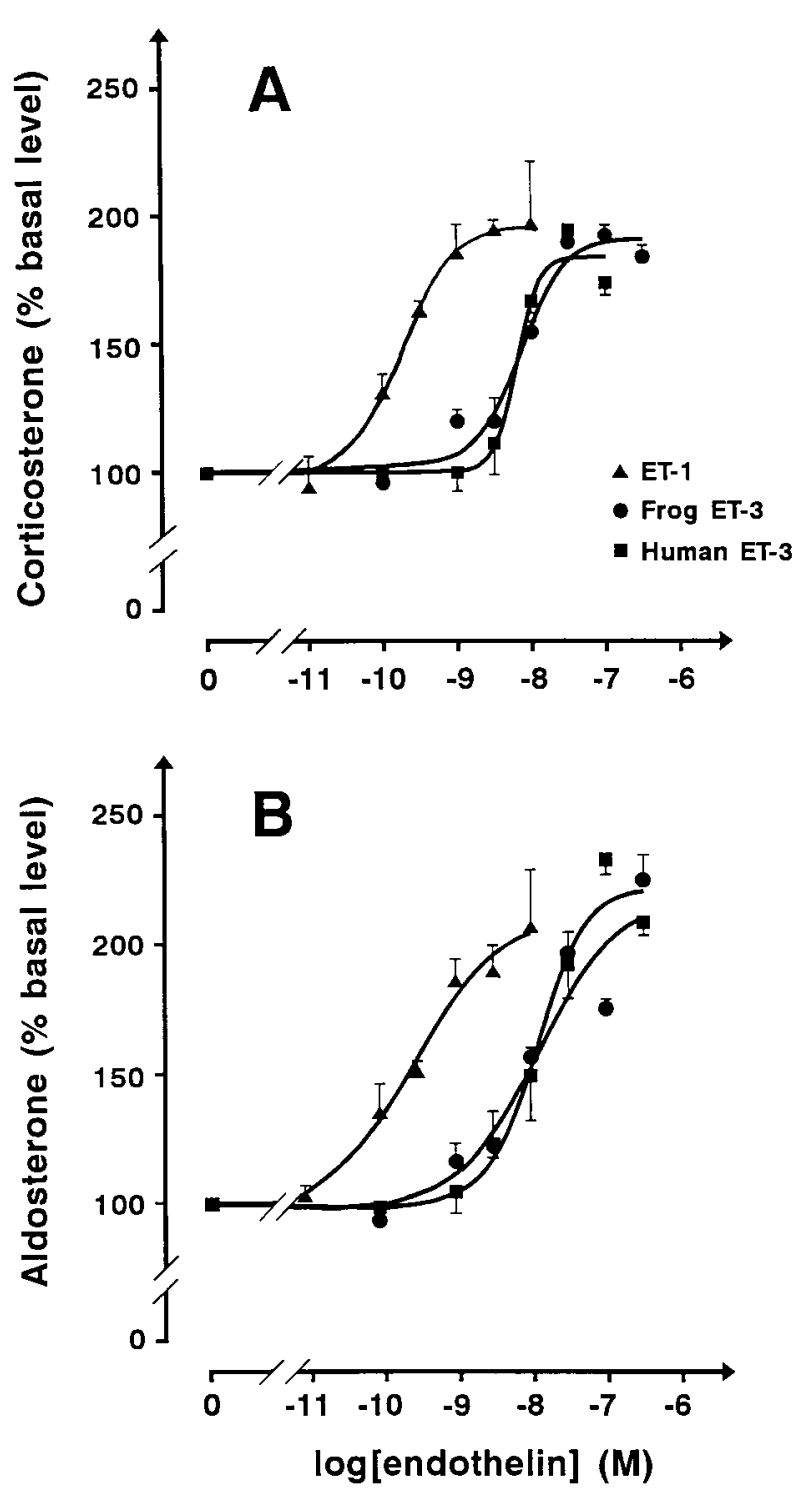

FIGURE 3. Semi-logarithmic plots comparing the effects of increasing concentrations of frog/human ET-1 $\left(10^{-11}\right.$ to $\left.10^{-8} \mathrm{M}\right)$, frog ET-3 $\left(10^{-10}\right.$ to $\left.5 \times 10^{-7} \mathrm{M}\right)$, human ET -3 $\left(10^{-10}\right.$ to $\left.5 \times 10^{-7} \mathrm{M}\right)$ on corticosterone $(\mathrm{A})$ and aldosterone secretion (B) by perifused frog adrenal explants. Results are expressed as a percentage of the basal secretory rate. Mean basal levels of corticosterone and aldosterone secretion in these experiments were $12 \cdot 1 \pm 1 \cdot 0$ and $5 \cdot 5 \pm 0 \cdot 4 \mathrm{pg} / \mathrm{min}$ per adrenal gland (frog/human ET-1), 9.0 $\pm 0 \cdot 5$ and $3 \cdot 7 \pm 0 \cdot 34 \mathrm{pg} / \mathrm{min}$ per adrenal gland (frog ET-3), and $11 \cdot 3 \pm 0 \cdot 5$ and $3 \cdot 5 \pm 0 \cdot 4 \mathrm{pg} / \mathrm{min}$ per adrenal gland (human ET-3) respectively.

three peptides are compared in Table 1. The data show that the potency of frog ET-3 in stimulating corticosterone and aldosterone production was not significantly different from human ET-3. Frog/ human ET-1 was significantly more potent than frog ET-3 and human ET-3 in stimulating corticosterone $(P<0 \cdot 01)$ and aldosterone $(P<0 \cdot 05)$. The efficacies of the three peptides on corticosteroid output (approximately a 2 -fold increase over basal rates of secretion) were not significantly different.

\section{DISCUSSION}

In a preliminary experiment using an antiserum that reacted strongly with the three isoforms of human ET in RIA, it was shown that ET-LI was present in all frog tissues examined (stomach, liver, kidney, interrenal gland, heart, brain and pituitary) with the exception of the skin. In view of the greater mass of the liver and stomach, and therefore greater amounts of ET in terms of pmol/organ, it was decided to utilize these two tissues as a source of ET for purification and characterization. Although it was possible to isolate sufficient material to permit structural characterization, the origin of the ET isolated from the frog stomach and liver is uncertain. While the purified material probably represents, at least in part, peptides that are synthesized in these tissues, it may also represent circulating ET that has been internalized by the organs through receptor-mediated endocytosis. Receptor-mediated uptake of circulating ET-3 by the rat liver has been described (Anggard et al. 1989) and the lysosomal compartment of bovine pulmonary endothelial cells has been shown to contain high concentrations of ET (Nakamura et al. 1990).

The amino acid sequence of each ET isoform has been strongly conserved among those mammalian species yet studied (human, pig, dog, rabbit, ox and rat, reviewed in Rubanyi \& Polokoff (1994)) with the only species-related sequence difference being the substitution $\mathrm{Ser}^{4} \rightarrow \mathrm{Asn}$ in mouse ET-2 (Saida et al. 1989). Our study has demonstrated that the primary structures of the peptides have been very strongly conserved throughout the evolution of tetrapods. As shown in Fig. 4, frog ET-1 is identical in structure to human ET-1, and frog ET-3 is the same as human ET-3 except for a single amino acid substitution $\left(\mathrm{Phe}^{4} \rightarrow \mathrm{Tyr}\right)$. A plausible hypothesis explaining the evolution of the ET family of peptides is that duplication of the gene encoding an ancestral ET gave rise to a gene encoding ET-3 and a second gene encoding the ancestor of ET-1 and ET-2. A subsequent duplication of this latter gene gave rise to separate genes encoding ET-1 and ET-2 (Landan et al. 1991). As all mammalian species yet studied synthesize the three ET isoforms, both gene 
TABLE 1. Effect of increasing concentrations of frog/human ET-1, frog ET-3 and human ET-3 on the rates of secretion of corticosterone and aldosterone by perifused frog adrenal glands. Potency refers to the $-\log \mathrm{EC}_{50}$ values and efficacy is expressed as the percent increase over mean levels of spontaneous steroid output $(100 \%)$. Values are given as mean \pm s.E.M. for between three and eight independent experiments

\begin{tabular}{|c|c|c|c|c|}
\hline & \multicolumn{2}{|c|}{ Corticosterone } & \multicolumn{2}{|l|}{ Aldosterone } \\
\hline & Potency & Efficacy & Potency & Efficacy \\
\hline \multicolumn{5}{|l|}{ Peptide } \\
\hline Frog/human ET-1 & $9 \cdot 81 \pm 0 \cdot 01$ & $198 \pm 1$ & $9 \cdot 52 \pm 0 \cdot 29$ & $222 \pm 30$ \\
\hline Frog ET-3 & $8 \cdot 13 \pm 0 \cdot 16^{*}$ & $190 \pm 9$ & $8 \cdot 15 \pm 0 \cdot 33^{+}$ & $203 \pm 19$ \\
\hline Human ET-3 & $8 \cdot 29 \pm 0 \cdot 34 *$ & $173 \pm 25$ & $7 \cdot 87 \pm 0 \cdot 18^{+}$ & $221 \pm 17$ \\
\hline
\end{tabular}

duplications are presumed to have occurred before the appearance of mammals. Our failure to isolate ET-2 from the frog tissues examined is consistent with, but of course does not prove, the view that the second gene duplication took place after the appearance of the Amphibia. Further work is clearly required, using specific probes for the frog ET isoforms in immunohistochemistry and/or in situ hybridization, to study the expression of ET genes in frog tissues.

The biosynthesis of the ET isoforms in mammals is unusual in that post-translational processing of preproendothelin at the site of dibasic amino acid residues by the well-characterized prohormone convertases produces a 'big' ET, of between 38 and

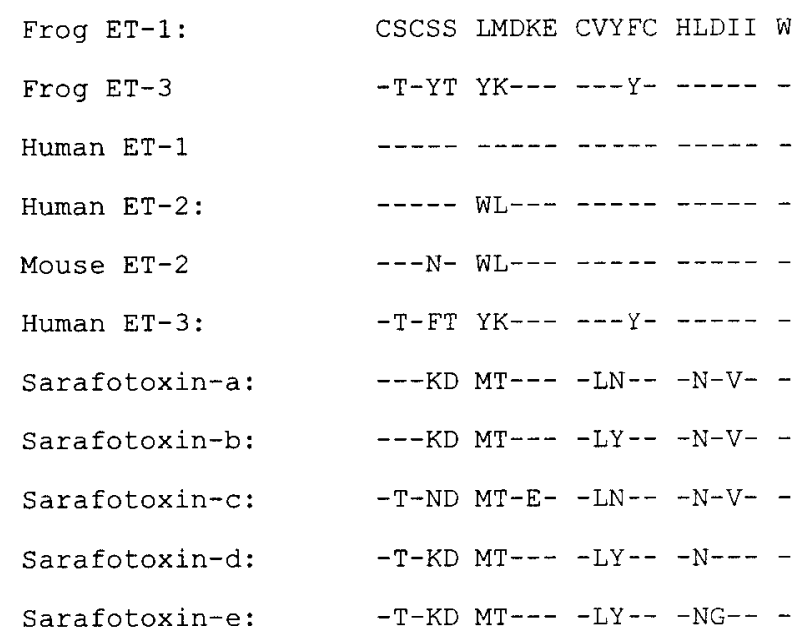

FIGURE 4. A comparison of the amino acid sequences of the naturally occurring ET-related peptides. The five isoforms of sarafotoxin were isolated from the venom of a snake. - - denotes that the amino acid residue has been conserved.

www.endocrinology.org
41 amino acids depending on the species, that has low biological potency (Kido et al. 1998). Big ET is further processed by a highly selective enzyme, ET-converting enzyme, that exists in several isoforms and cleaves at the $\operatorname{Trp}^{21}-\mathrm{Val}^{22}$ bond in big ET-1 and ET-2 and at the Trp ${ }^{21}-\mathrm{Ile}^{22}$ bond in big ET-3 (Shimada et al. 1995). The isolation of frog ET-1 and ET-3 in 21 amino acid residue forms suggests that preproendothelins are processed in amphibia by a pathway similar to that in mammals. Our data do not exclude the possibility that big ET isoforms are present in frog tissues, as the antiserum used in this study for detection does not recognize big ET.

The effects and mechanism of action of ET on steroidogenesis in the perifused interrenal gland of $R$. ridibunda have been studied in detail using synthetic human ET-1 and ET-3. The data show ET-1 produces a concentration-dependent increase in the production of corticosterone and aldosterone (Delarue et al. 1990) that involves the activation of the cyclooxygenase, the phospholipase $\mathrm{C}$ and the adenylate cyclase transduction pathways (Delarue et al. 1990, Cartier et al. 1999). It has also been shown that the steroidogenic action of human ET-1 requires an intact microfilament network in the interrenal gland, whereas microtubules and intermediate filaments are not involved (Remy-Jouet et al. 1994). In mammals, the biological actions of ET are mediated through interaction with two well-characterized receptors. The $\mathrm{ET}_{\mathrm{A}}$ receptor is selective for ET-1 and ET-2 and binds ET-3 with approximately 100 -fold less affinity, whereas the $\mathrm{ET}_{\mathrm{B}}$ receptor exhibits similar affinities for all three isopeptides (Sokolovsky 1995). Previous studies have indicated that the receptor mediating the effects of ET on the frog interrenal gland resembles the mammalian $\mathrm{ET}_{\mathrm{A}}$ subtype more closely than the 
$\mathrm{ET}_{\mathrm{B}}$ subtype. In this tissue, the $\mathrm{ET}_{\mathrm{A}}$ receptor antagonist, $\mathrm{BQ}-485$, inhibited the steroidogenic effect of ET-1, whereas the selective $\mathrm{ET}_{\mathrm{B}}$ receptor agonist, IRL 1620, was without effect (Cartier et al. 1997).

The present study has compared the effects of frog/human ET-1, frog ET-3 and human ET-3 on corticosterone and aldosterone production using perifused interrenal glands of frogs that were bred and housed under identical conditions. The observation that frog ET-1 is between 33 times (aldosterone) and 49 times (corticosterone) more potent than frog ET-3 supports the earlier conclusion that the steroidogenic action of ET is mediated through a receptor subtype that resembles the mammalian $\mathrm{ET}_{\mathrm{A}}$ receptor more closely than the mammalian $\mathrm{ET}_{\mathrm{B}}$ receptor. A third receptor subtype $\left(\mathrm{ET}_{\mathrm{C}}\right)$ that binds ET-3 with higher affinity than either ET-1 or ET-2 has been identified in X. laevis dermal melanophores (Karne et al. 1993), but its physiological significance is unclear. The lower potency of frog ET-3 compared with ET-1 indicates that the $\mathrm{ET}_{\mathrm{C}}$ receptor does not appear to be important in mediating steroidogenesis in $R$. ridibunda. The observation that frog ET-3 is equipotent with human ET-3 demonstrates that the substitution $\left(\mathrm{Phe}^{4} \rightarrow \mathrm{Tyr}\right)$ is not important in determining binding of ligand to the amphibian $\mathrm{ET}_{\mathrm{A}}$ receptor. This result was expected in the light of the observation that replacement of $\mathrm{Ser}^{4}$ by Ala in human ET-1 had only minimal effect on the $\mathrm{ET}_{\mathrm{A}}$-receptor mediated constriction of vascular rings from the rat pulmonary artery (Nakajima et al. 1989).

\section{ACKNOWLEDGEMENTS}

This work was supported by grants from NSF (IBN-9806997), INSERM (U413), an INSERMFRSQ exchange program and the Conseil Régional de Haute-Normandie. H V is an Affiliated Professor at the Institut National de la Recherche Scientifique-Santé, Montréal, Canada. The authors thank Per F Nielsen, Novo Nordisk, Bagsvaerd, Denmark for mass spectrometry measurements and Dr S R Bloom, Imperial College Medical School, London and Dr T E Adrian, Creighton University Medical School, for gifts of antisera.

\section{REFERENCES}

Anggard E, Galton S, Rae G, Thomas R, McLoughlin L, deNucci G \& Vane JR 1989 The fate of radioiodinated endothelin-1 and endothelin-3 in the rat. Fournal of Cardiovascular Pharmacology 13 S46-S49.
Belloni AS, Rossi GP, Andreis PG, Neri G, Albertin G, Pessina AC \& Nussdorfer GG 1996 Endothelin adrenocortical secretagogue effect is mediated by the $\mathrm{B}$ receptor in rats. Hypertension 27 1153-1159.

Cartier F, Remy-Jouet I, Fournier A, Vaudry H \& Delarue C 1997 Effect of endothelin-1 on corticosteroid secretion by the frog adrenal gland is mediated by an endothelin ${ }_{\mathrm{A}}$ receptor. Endocrinology 138 4358-4363.

Cartier F, Delarue C, Remy-Jouet I, Kodjo MK, Fournier A \& Vaudry H 1999 The stimulatory effect of endothelin-1 on frog adrenocortical cells is mediated through both the phospholipase $\mathrm{C}$ and the adenyl cyclase transduction pathways. Molecular and Cellular Endocrinology 147 27-36.

Chartrel N, Wang Y, Fournier A, Vaudry H \& Conlon JM 1995 Frog vasoactive intestinal polypeptide and galanin: primary structures and effects on pituitary adenylate cyclase. Endocrinology 136 3079-3086.

Cozza EN, Gomez-Sanchez CE, Foecking MF \& Chiou S 1989 Endothelin binding to cultured calf adrenal zona glomerulosa cells and stimulation of aldosterone secretion. Fournal of Clinical Investigation 84 1032-1035.

Delarue C, Delton I, Fiorini F, Homo-Delarche F, Fasolo A, Braquet P \& Vaudry H 1990 Endothelin stimulates steroid secretion by frog adrenal gland in vitro: evidence for the involvement of prostaglandins and extracellular calcium in the mechanism of action of endothelin. Endocrinology 127 2001-2008.

Doi Y \& Fujimoto S 1993 Vasocontractions of the in vivo toad aortas induced by endothelin-1 and sarafotoxin-S6b. Anatomical Record 235 253-260.

Forget MA, Lebel N, Sirois P, Boulanger Y \& Fournier A 1996 Biological and molecular analyses of structurally reduced analogues of endothelin-1. Molecular Pharmacology 49 1071-1079.

Inoue A, Yanagisawa M, Kimura S, Kasuya Y, Miyauchi T, Goto K \& Masaki T 1989 The human endothelin family: three structurally and pharmacologically distinct isopeptides predicted by three separate genes. Proceedings of the National Academy of Sciences of the USA 86 2863-2867.

Karne S, Jayawickreme CK \& Lerner MR 1993 Cloning and characterization of an endothelin-3 specific receptor $\left(\mathrm{ET}_{\mathrm{C}}\right.$ receptor) from Xenopus laevis dermal melanophores. Fournal of Biological Chemistry 268 19126-19133.

Kido T, Sawamura T \& Masaki T 1998 The processing pathway of endothelin-1 production. Fournal of Cardiovascular Pharmacology 31 S13-S15.

Kumar CS, Nuthulaganti P, Pullen M \& Nambi P 1993 Novel endothelin receptors in the follicular membranes of Xenopus laevis oocytes mediate calcium response by signal transduction through gap junctions. Molecular Pharmacology 44 153-157.

Kumar C, Mwangi V, Nuthulaganti P, Wu HL, Pullen M, Brun K, Aiyar H, Morris RA, Naughton R \& Nambi P 1994 Cloning and characterization of a novel endothelin receptor from Xenopus heart. Fournal of Biological Chemistry 269 13414-13420.

Landan G, Bdolah A, Wollberg Z, Kochva E \& Graur D 1991 Evolution of the sarafotoxin/endothelin superfamily of proteins. Toxicon 29 237-244.

Morishita R, Higaki J \& Ogihara T 1989 Endothelin stimulates aldosterone biosynthesis by dispersed rabbit adrenocapsular cells. Biochemical and Biophysical Research Communications $160628-632$.

Nakajima K, Kubo S, Kumagaye SI, Nishio H, Tsunemi M, Inui $\mathrm{T}$, Kuroda $\mathrm{H}$, Chino N, Watanabe TX, Kimura $\mathrm{T} \&$ Sakakibara S 1989 Structure-activity relationship of endothelin: importance of charged groups. Biochemical and Biophysical Research Communications 163 424-429. 
Nakamura S, Naruse M, Naruse K, Demura H \& Uemura H 1990 Immunocytochemical localization of endothelin in cultured bovine endothelial cells. Histochemistry 94 475-477.

Nambi P, Pullen M \& Kumar C 1994 Identification of a novel endothelin receptor in Xenopus laevis liver. Neuropeptides $\mathbf{2 6}$ 181-185.

Poder TC, Silberberg SD \& Rampe D 1991 Contraction of reptile, amphibian, and fish blood vessels by endothelin-1. Canadian Fournal of Physiology and Pharmacology 69 215-217.

Remy-Jouet I, Delarue C, Feuilloley M \& Vaudry H 1994 Involvement of the cytoskeleton in the mechanism of action of endothelin on frog adrenocortical cells. Fournal of Steroid Biochemistry and Molecular Biology 50 55-59.

Rossi GP, Albertin G, Neri G, Andreis PG, Hofman S, Pessina AC \& Nussdorfer GG 1997 Endothelin-1 stimulates steroid secretion of human adrenocortical cells ex vivo via both $\mathrm{ET}_{\mathrm{A}}$ and $\mathrm{ET}_{\mathrm{B}}$ receptor subtypes. Fournal of Clinical Endocrinology and Metabolism 82 3445-3449.

Rubanyi GM \& Polokoff MA 1994 Endothelins: molecular biology, biochemistry, pharmacology, physiology, and pathophysiology. Pharmacological Reviews 46 325-415.

Saida K, Mitsui Y \& Ishida N 1989 A novel peptide, vasoactive intestinal contractor, of a new (endothelin) peptide family. Molecular cloning, expression, and biological activity. Fournal of Biological Chemistry 264 14613-14616.
Shimada K, Takahashi M, Ikeda M \& Tanzawa K 1995 Identification and characterization of two isoforms of an endothelin-converting enzyme-1. FEBS Letters 371 140-144.

Simonson MS 1993 Endothelins: multifunctional renal peptides. Physiological Reviews 73 375-411.

Sokolovsky M 1995 Endothelin receptor subtypes and their role in transmembrane signalling mechanisms. Pharmacology and Therapeutics 68 435-471.

Suzuki H, Yamamoto T, Kikuyama S \& Uemura H 1997 Distribution of endothelin 3-like immunoreactivity in gonadotrophs of the bullfrog (Rana catesbeiana) pituitary. General and Comparative Endocrinology 107 12-22.

Takahashi K, Suda K, Lam H-C, Ghatei MA \& Bloom SR 1991 Endothelin-like immunoreactivity in rat models of diabetes mellitus. Fournal of Endocrinology 130 123-127.

Takasaki C, Tamiya N, Bdolah A, Wollberg Z \& Kochva E 1988 Sarafotoxins S6: several isotoxins from Atractaspis engaddensis (burrowing asp) venom that affect the heart. Toxicon 26 543-548.

Takasaki C, Itoh Y, Onda H \& Fujino M 1992 Cloning and sequence analysis of a snake, Atractaspis engaddensis gene encoding sarafotoxin S6c. Biochemical and Biophysical Research Communications 189 1527-1533.

RECEIVED 2 August 1999 